\title{
PHYSICAL EDUCATION IN THE REPUBLIC OF SERBIA
}

\section{EDUCACIÓN FÍSICA EN LA REPUBLICA DE SERBIA}

\author{
Snežana Radisavljević Janić, Ivana Milanović \\ Faculty of Sport and Physical Education, University of Belgrade, Serbia.
}

\begin{abstract}
Physical education, as an integral part of compulsory education, plays a significant role in promoting and improving the physical activity of children and youth. Having regard to the changes occurred in some segments of physical education, during the period of the full state sovereignty of the Republic of Serbia, the analysis included the following: legal framework and adopted documents, PE curriculum and program, physical education teaching conditions, educational standards, teaching staff, physical education exemptions and research in the field of physical education. The importance of physical education, which has been recognized in the legal framework, by the recommendations contained in the adopted regulations and measures, has not been implemented or practically applied. In this sense, an increased number of PE classes and uniform conditions for physical education teaching at the state level, i.e. throughout the country, should be set as a priority. The emphasis which has moved away from the curriculum and learning content towards the learning process and its outcomes, introduction of the mandatory monitoring, evaluating and recording of pupils' physical abilities and allowing pupils to be exempted only from a practical part of the PE course with an obligation to attend PE classes represent significant novelties within the subject bearing a new name (Physical and Health Education). It is necessary to assess the achievement level of educational standards, i.e. to examine the extent to which pupils have acquired knowledge and skills and developed their motor abilities upon completion of their compulsory education. Mandatory professional development of PE teachers aimed at acquiring new competences and strengthening the existing ones is important for the improvement of educational work. The research results have indicated that it is necessary to continuously monitor the prevalence of obesity and level of physical activity and motor abilities in pupils at the national level, as well as to promote healthy eating habits and encourage children to engage in physical activity and exercise.
\end{abstract}

Key words: PHYSICAL EDUCATION /CURRICULUM AND PROGRAM / EDUCATIONAL STANDARDS / SERBIA

\section{EXTRACTO}

La educación física, como parte integral de la educación obligatoria, tiene un papel importante en la promoción y fomento de la actividad física de los niños y jóvenes. En relación con los cambios en algunos segmentos de la educación física, en el período desde la plena independencia estatal de la República de Serbia, el análisis abarcó: el marco legal y los documentos aprobados, el plan y programa, las condiciones para la enseñanza de la educación física, las normas de educación, el personal docente, la liberación de alumnos de participar en la enseñanza de la educación física e investigaciones en la educación física. La importancia de la educación física que fue reconocida en el marco legal con las recomendaciones en las decisiones y medidas aprobadas no se transfirió en la práctica. En ese contexto, el aumento del número de clases y ecualización de las condiciones para la enseñanza de la educación física en el nivel de todo el Estado deberían ponerse como prioridad. El cambio de enfoque de los contenidos de enseñanza al proceso de estudio y sus resultados, introducción de seguimiento obligatorio, evaluación y evidencia de las capacidades físicas de los alumnos y liberación de alumnos sólo de la parte práctica de la enseñanza, con la presencia obligatoria en las clases, son unas novedades importantes en el marco de la asignatura con un nuevo título (la educación física y de salud). Es imprescindible averiguar el alcance de las normas educativas, es decir ¿en qué medida los alumnos consiguieron conocimientos y habilidades y desarrollaron las capacidades motrices al final de la educación obligatoria? La capacitación profesional obligatoria de los profesores de la educación física con el fin de conseguir nuevas competencias y perfeccionar las existentes es importante para la promoción del trabajo educativo-instructivo. Los resultados de la investigación indican la necesidad de seguir continuamente la prevalencia de obesidad, el nivel de la actividad física y capacidades motrices de los alumnos en el nivel nacional, como también la promoción de la dieta saludable y el estímulo de la actividad física entre los niños.

Palabras claves: EDUCACIÓN FÍSICA/ PLAN Y PROGRAMA/ NORMAS EDUCATIVAS / SERBIA 


\section{INTRODUCTION}

School is the most important institution in promoting and improving the physical activity of children and young people (McBride and Midford 1999; Cardon and Bourdeaudhuij 2002), and physical education plays a key role in this process (Shephard and Trudeau 2000). Physical education, as a school subject, has an extended role and special responsibility, which is reflected by the fact that the content of PE course deals with many contemporary issues in the educational process in addition to the characteristics that cannot be provided by any other school subject or learning content (Hardman, 2009). Also, it is "the only school subject which prepares children for a healthy life, being oriented towards their overall physical and mental development. Many important social values such as fairness, self-discipline, solidarity, tolerance, team spirit and fair play are transferred through teaching Physical Education," furthermore, it is, in addition to sports, considered "one of the most important social integration tools" (Hardman, 2009). Physical education is an integral part of compulsory education, both in European countries and Serbia. Having regard to the changes occurred in some segments of physical education, during a period of ten years, the analysis included the following: Legal Framework and Adopted Documents, PE Curriculum and Program, Physical Education Teaching Conditions, Educational Standards, Teaching Staff, Physical Education Exemptions and Research in the Field of Physical Education.

\section{PHYSICAL EDUCATION: LEGAL FRAMEWORK AND ADOPTED DOCUMENTS}

In a wider social context, Physical Education (PE) can be also viewed through the importance attached to it by the law and adopted documents. According to the Law on Foundations of Education System $(2009,2017)$, one of the educational goals that can be achieved through physical education teaching is „developing and leading healthy lifestyles and fostering an awareness of the importance of one's own health and safety as well as developing and improving physical abilities." The importance of physical education, some problems that this subject has been faced with as well as possible courses of action have been specified in various documents adopted at the level of the Republic of Serbia. In the Strategy for Development of Education in Serbia by 2020 (2012) it has been stated that "the child development support provided by health and sports has been quite poor. Sport is available mainly to talented pupils, and in spite of being a part of regular school activities oriented towards children's development and investment in their health, extra-curricular sports activities at schools have been charged for, a large number of pupils have been exempted from physical education classes, and the objective needs are growing." In Serbia, the problem of insufficient and inadequate physical activity has reached national importance, which has been indicated by the adoption of a Decree on the National Program for Prevention, Treatment and Control of Cardiovascular Diseases in the Republic of Serbia by 2020 (2010), specifying that $18.3 \%$ of the population are overweight, and $74.3 \%$ are not physically active enough. One of the measures included therein is a need to "harmonize the recommendations given by health professionals in terms of increasing the number of physical education classes in the curricula and programs of regular physical education courses in primary and secondary education".

Having considered the overall worrying situation related to psychological and physical abilities of children and youth, postural disorders and a growing number of chronic, noncommunicable diseases as a result of living conditions and insufficient physical activity, the National Education Council, at its $78^{\text {th }}$ session, held on May 29, 2012, concluded that it is necessary to establish a broad, inter-ministerial working group that should propose the measures to be taken in order to improve the health and psychological and physical abilities of children and youth. The measures to improve physical education teaching were adopted in 2013, concluding that it is necessary to ,improve the conditions for the realization of physical education course as an integral part of the education system." 


\section{PHYSICAL EDUCATION PROGRAM AND CURRICULUM}

Physical education is a compulsory subject in primary and secondary schools. In the first cycle of elementary education ( $1-4^{\text {th }}$ grade), three PE classes are realized per week, and in the second cycle of elementary education (5- $8^{\text {th }}$ grade), a weekly number of PE classes is 2 . The third physical education class per week was introduced and regulated pursuant to the Professional Instructions on the Organization of Sports Activities in Primary Education (No. 110-00449-05/02 as of June 22, 2005), issued by the Minister of Education and Sports, which was followed by the introduction of the Mandatory Program of School Sports- Selected Sports Discipline, which was realized by one class per week and included in the Curriculum of Primary Education. In 2007, this program was replaced by a completely new subject named Physical Education - Selected Sports, belonging to the group of compulsory-elective subjects (Official Gazette of the Republic of Serbia, no. 6/2007).

In the school year 2017/2018, instead of physical education, and in accordance with the request of the Ministry of Education, Science and Technological Development, a new school subject named Physical and Health Education was introduced to the fifthgrade pupils, which conditioned the „incorporation” of health education course and program content into the curriculum (Rulebook on amendments and supplements to the rulebook on the curriculum for the second cycle of elementary education and the program for the fifth grade of primary school, 2017). This subject has been realized by 2 classes of physical and health education per week and 1.5 classes of compulsory physical activity. The program of the former subject of physical education - selected sports has been now comprised in the pupils' compulsory physical activities (1.5 classes per week) and integrated in the curriculum, supplemented with new content.

In this paper, the curricula for these subjects have been presented in regard to the following elements: goal, objectives, themes, i.e. subject areas, content, organizational forms of work and methodical instructions for course implementation. The goal of physical education course is to contribute to the integral development (cognitive, affective and motor) of a pupil's personality, development of their motor abilities, acquisition, development and application of motor skills, development of habits and values, application of acquired and theoretical knowledge necessary in everyday situations and specific living and work conditions, using diverse and systematic motor activities and in connection with other fields of education. This physical education program has precisely defined the goal of physical education by specifying the following objectives of physical education course: encouraging growth and development and affecting the proper body posture; developing and improving motor abilities; acquiring the motor skills determined as the physical education program content as well as the theoretical knowledge necessary for the implementation thereof; acquiring knowledge in order to understand the importance and idea of physical education defined by the goal of this subject area; formation and development of moral values, attitudes and personal qualities; training pupils to apply the acquired skills, knowledge and habits in everyday living and work conditions; acquisition and development of an awareness of the importance of health and healthcare and the need to protect and preserve nature and the environment. The program of this school subject is aimed at: development of physical abilities, acquisition of motor skills, abilities and habits and theoretical knowledge. The program content includes the following: athletics, floor exercises and exercises using apparatus, sports games (handball, basketball, volleyball) and rhythmic gymnastics and folk dances. In addition to physical education classes, as the basic organizational form of work, other organizational forms of work have been also envisaged, which should contribute to the acquisition of those skills and habits that are relevant for everyday life and they are carried out as out-of-school or extra-curricular activities: corrective exercises and pedagogical work, optional activities - extra-curricular, outdoor activities (excursions, trips, cross-country, camping, ski trips), school and other competitions, sports activities of importance for the social environment and course work methods. The program comprises detailed didactic and methodical instructions for its implementation.

Learning objectives of all the subjects taught in the fifth grade of primary school have been newlydesigned and defined so that the emphasis has been shifted from the learning content towards the learning outcomes. Accordingly, the goal of physical and health education course is to improve pupils' physi- 
cal abilities, motor skills and knowledge in the field of physical culture and culture of health, in order to preserve health and apply proper and regular physical exercise in contemporary living and work conditions. Instead of themes, the following subject areas have been defined: Physical abilities, Motor skills, Sports and sports disciplines and Physical and health culture. The program content includes the following: Athletics, Sports Gymnastics, Basics of Team Sports and Sports Games, Dance and Rhythmic and Swimming. The overall course content has been divided into the mandatory and recommended sections, taking into consideration the pupils' age and material and technical capacities of schools. The program comprises the following organizational forms of work: physical and health education classes; pupils' compulsory physical activity; optional activities - extra-curricular; week of school sports; outdoor activities (cross-country, ski trips, summer camps); school and out-of-school competitions; corrective exercises - pedagogical work. Didactic and methodical elements have been reduced to basic information.

The major change in the contemporary concept and practice of education, as well as in the curriculum for physical and health education subject, is the emphasis which has shifted from the content towards the clearly defined outcomes, i.e. from the learning content to the learning process and its outcomes. The outcomes have been formulated to provide a description of what pupils will be able to do upon completion of the subject area/theme.

The subject of physical and health education includes the mandatory monitoring, evaluation and recording of pupils' physical abilities, which should be conducted at the beginning and at the end of a school year, based on the Guidelines for monitoring pupils' physical development and development of their motor abilities in physical education classes (Institute for Education Quality and Evaluation, 2016). These Guidelines have explained the following in detail: a model of continuous monitoring of physical development and motor abilities, test battery, criterionreferenced values and method of their interpretation, testing organization and test protocol as pedagogical implications.

\section{PHYSICAL EDUCATION TEACHING CONDITIONS}

In addition to a number of PE classes, content of physical education program, number of pupils and teachers' competences, facilities and equipment represent one of the factors that affect the quality of physical education. Although it has been stipulated in the Rulebook on the norms and standards of school premises, equipment and teaching aids in primary schools (1990) that all independent, i.e. main, primary schools should have a gym with ancillary premises for physical education classes, the conditions for physical education teaching in our educational system are not uniform in the territory of the entire country, and a comprehensive analysis thereof has never been conducted. An analysis of the facilities intended for the realization of physical education classes in 96 primary and secondary schools in the territory of the city of Belgrade was done almost two decades ago. The results showed that $65.6 \%$ of schools were equipped with indoor gyms, $64.6 \%$ of schools had outdoor playgrounds, $32.3 \%$ of schools had ancillary premises, $53.1 \%$ of schools were equipped with apparatus rooms, $78.1 \%$ of the schools examined had teachers' rooms. Approximately $10.4 \%$ of the schools were provided with the conditions for teaching in a reduced form (Nikolić, 2003-2004). The obtained results have indicated that about $20 \%$ of schools in the territory of the city of Belgrade were not equipped with indoor gyms at the time of analysis. It has remained unclear how the physical education classes were actually conducted and realized in these schools. The conditions for physical education teaching in 1533 schools (1135 primary and 398 secondary schools) of the Republic of Serbia were analyzed in the Study on the situation in the educational institutions in Serbia in regard to school sports (Institute for Education Quality and Evaluation, 2008). The results have shown that $63.5 \%$ of schools had a large gym and $22.4 \%$ of schools were equipped with a small gym. An abundance of data obtained in this research cannot provide a conclusion about a number of schools that are not equipped with a gym for physical education teaching. It is necessary to prepare a rulebook on the norms and standards of school premises, equipment and teaching aids for physical education in the education system. Also, it is required to conduct an analysis of the current situa- 
tion about the conditions and equipment for physical education teaching, which would represent the beginning of defining a plan for solving this problem.

\section{TEACHING STAFF}

This chapter includes an analysis of the following: qualifications and education of the teaching staff, master degree as a necessary requirement for working in the field of education, teachers' professional training and standards of teachers' competences and their professional development. The education of staff for working in the field of PE is carried out at four state faculties of sport and physical education, namely in Belgrade, Novi Sad, Niš and Leposavić, as well as at the State faculty in Novi Pazar within the Department of Biomedical Sciences. In addition to these state faculties, teaching staff is also being educated to work in education at a number of private faculties. Since the school year 2005/06, a master degree has been a prerequisite for working in education. Professional training has become an integral and mandatory part of the teachers' professional development, which implies acquiring the new competences and improving the existing ones relevant for the improvement of teaching and educational work (Rulebook on continuous professional development and acquisition of the title of teachers, educators and professional associates, 2013). The teachers' personal professional development plans have been based on the self-assessment of a development level of all the competences for teachers, educators and professional associates. PE teachers, as well as all other teachers, are obliged to collect a minimum of 100 points achieved in various forms of professional training within five years, including at least 80 points achieved in the approved professional training programs (Rulebook on Continuing Professional Development of Teachers, Educators and Professional Associates, 2015). The catalogue of professional development programs and courses, approved by the Institute for the Improvement of Education, includes some professional training programs and courses intended for physical education teachers. The number of these programs ranges from 6 in the school year 2006/2007 to 29 in 2018/20 (2006/2007 - 6; 2007/2008 - 10; 2008/2009 - 13; 2009/20010 - 22; 2010/2011 - 9; 2011/2012 - 8; 2012/2014 - 12;
2014/2016 - 14; 2016/2018 - 23 and 2018/20 - 29).

Since 2011, the standards of competences for teachers and their professional development have been established (Rulebook on the standards of competences for teachers and their professional development, 2011). For all teachers, including physical education teachers, teachers' competences represent the capacity of an individual demonstrated by performing complex tasks in educational work. The teachers' competences are a set of necessary knowledge, skills, attitudes and values. These competences have been determined in relation to learning outcomes and goals and they should provide professional standards of a type of teaching which is considered to be successful. They include the competencies related to the following: subject area, course and teaching methodology; teaching and learning; support to the pupil's personality development and communication and cooperation.

\section{EDUCATIONAL STANDARDS}

Within the Support to the quality assurance of the system of final national exams in primary and secondary education project (IPA 2008), the educational standards relating to the completion of compulsory education have been developed and adopted for all subjects, including physical education. The educational standards relating to the completion of compulsory education for PE subject were adopted in 2009 (Education Gazette, 2009). Educational standards are the statements about the basic knowledge and skills that pupils should acquire having reached a certain education level. The educational standards for PE subject have been defined in relation to four areas: trained and acquired skills, knowledge of physical exercise and physical education, and assessment and evaluation of physical exercise and physical education performed by pupils. The area of trained and acquired skills consists of the PE course content mastered in sports games (basketball, volleyball, handball or football), athletics (running, jumping, throwing), floor exercises and exercises using apparatus (floor, vault, beam, uneven bars, rings, pommel horse, parallel bars, high bar), dance, rhythmic gymnastics, swimming, toning exercises and table tennis. The area of knowledge regarding physical exercise and physical education consists 
of the terms used in physical exercise, knowledge of the basic principles of exercise and the rules of sports games and individual sports. The area of evaluation and assessment of physical exercise and physical education by pupils comprises the beliefs, attitudes and values that a pupil possesses upon completion of primary education in physical exercise and physical education. The standards are periodically revised and upgraded, and the revision of educational standards was performed in 2013 under the project named Support to Human Resources Development and Research - General Education and Human Resources Development "Razvionica” (IPA, 2011). In addition to the three PE areas defined above, the area of motor skills has been also proposed, therefore, the educational standards for the PE subject have been defined for the following areas: the area of trained and acquired skills which refers to acquiring the following elements: one sports game, athletics, exercises using apparatus and floor exercises, dance, rhythmic gymnastics, swimming and toning exercises; the area of motor abilities relates to the development of pupils' motor skills in relation to their gender and age; knowledge of physical exercise and physical education includes the terms and concepts of physical exercise and the basic rules of exercise, rules of sports games and individual sports, idea and impact of physical exercise and evaluation and assessment of physical exercise and physical education imply the pupils' beliefs, attitudes, interests, team work, self-actualization through physical exercise, physical activity and physical education process. It is necessary to note that the educational standards for PE within the Razvionica project (IPA, 2011) were one of the basis for defining the PE outcomes, and they have been also used to define the outcomes of the Curriculum for the Fifth Grade.

\section{PHYSICAL EDUCATION CLASSES EXEMPTIONS}

The pupils' exemption from physical education classes has been regulated by the legal framework, in accordance with the Law on Primary Education (2013, Article 65), as well as the Law on Secondary Education (2013, Article 50), which provide for a possibility of physical education exemptions. The Ministry of Education prescribed a bylaw on the implementation of the aforementioned Articles of the Law in a form of the Professional Instructions in 1993. Under these Professional Instructions it has been stipulated that a proposal on the exemption of primary and secondary school pupils from the physical education classes may be provided by a specialist doctor or a school doctor, depending on the pupil's health status or a reasonable cause of such an exemption. A pupil can be exempted from $\mathrm{PE}$ classes temporarily or in a specific school year, either partially or totally, provided that the pupil, due to his/her health condition is not able to master the content prescribed uder the physical education curriculum. In the event of a temporary or a partial exemption from the physical education classes, the pupil's performance shall be assessed in relation to the part of the PE course in which he/she participated and the pupil is obliged to attend all PE classes. As for a total exemption from the physical education classes in a specific school year, the pupil's performance in this course shall not be assessed and the pupil will not be obliged to attend the PE classes should these be included in a weekly timetable as the first class or the last one. A request for a physical education exemption can be submitted by a pupil or his/her parent (guardian). The complete request submitted by the pupil shall be discussed and considered at a meeting of the teacher's council, who shall decide on exempting the pupil from the physical education classes.

Physical education as a compulsory subject taught in primary and secondary schools has significantly contributed to the improvement of pupils' school and out-of-school physical activity and exercise, however, it has been faced with the problem of a large number of PE exempt pupils. This problem has been present ever since physical education became a part of the educational process, and today, it can have serious negative effects on pupils, unless a step is taken to reach its resolution. Although a small number of studies have indicated a large number of pupils exempted from physical education classes, at the national level, there is no data on the number of exempt pupils in our country. According to the findings of a study on the current condition of the pupils exempted from the physical education classes in ten primary and seven secondary schools in the city of Belgrade in the school year 2012/13, a percentage of the pupils exempted from physical education in primary schools ranged between $0 \%$ and $1.6 \%$, and, in secondary 
schools, it ranged from $1.1 \%$ to $8.3 \%$ (Mićić, 2013). Should physical education exemptions be viewed through the total number of the exempted students in this research, it would result in a disturbing image. In seven secondary schools there were 249 exempt pupils, which practically means that 8 classes of pupils were excluded from the physical education course. On average, around $3.7 \%$ of pupils were exempted from the physical education classes, which may be not so alarming at firt sight, however, if the problem is observed from the aspect of a total number of the enrolled pupils, it means that out of 78,000 pupils enrolled in high schools and secondary vocational schools in Serbia in the school year of 2012/2013, there could be around 2,880 pupils, i.e. 96 classes of pupils, exempted from the physical education classes throughout the country. Such presumed figures may indicate a serious problem from the aspects of education and healthcare. The results of a study conducted in 2016 (Šunkić, 2016) have shown a similar trend of physical education exemptions in all primary and secondary schools in Pančevo. The physical education exemptions in primary schools were determined to be at the level of $0-3 \%$ of pupils, while in secondary schools it was even more pronounced, ranging from $1-10 \%$ of pupils. According to the findings of the two studies presented above and according to the teachers who work at the examined schools, some conclusions can be drawn as follows. In primary schools, the pupils are most often exempt due to health reasons, and in secondary schools, a higher number of pupils are exempted from physical education classes not solely for health reasons, but due to the support and assistance of their parents and the responsible physicians, and without a due health reason. Physical education teachers believe that the existing procedure for physical education exemptions can be improved. According to the physical education teachers (Šunkić, 2016), it is necessary to introduce subject teaching in lower primary school and a training about the importance of physical education as well as to introduce new programs in accordance with pupils' interests and abilities. In order to reduce the number of pupils exempted from physical education, a course of action should be directed towards the school level, through teaching pupils the importance of physical education, tailoring PE classes to the needs of pupils who have minor health problems and organizing more activities aimed at physical exercise promotion, and at the level of a wider social community, it should be carried out through informing the public about the values of physical education and a more comprehensive promotion of physical exercise.

The Law on Foundations of Education System (2017) has provided a new definition of physical education exemptions, whereby this problem has been confirmed to be observed at the level of the Republic of Serbia. According to this law, „a pupil may be exempted, temporarily or during a specific school year, from a practical part of the physical and health education course, either totally or partially. The Director shall decide on exempting the pupil from the physical and health education practical classes on a chosen physician's proposal. The performance of a pupil exempted from the practical part of physical and health education course shall be assessed on the basis of theoretical knowledge and in accordance with the curriculum." In the Physical and Health Education Curriculum for the Fifth Grade (2017), it has been more precisely defined that a pupil can be exempted only from a practical part of the course for a specific period, semester or entire school year based on the recommendations of a chosen physician. The pupil exempted from the practical part of PE course is obliged to attend PE classes. A special work program based on acquiring theoretical knowledge and educational content, in accordance with the curriculum and in a correlation with the contents of other subjects, shall be prepared by the PE teacher in order to work with exempt pupils. Also, exempt pupils should be given an opportunity to: act as referees, keep statistical records, register the results or achievements performed by other pupils or monitor a level of pupils' performance in classes or school competitions, design an educational poster or prepare an electronic presentation, write a sports report about a sporting event, record classes, or otherwise assist the teacher in the organization of classes, out-of-school and extra-curricular activities.

\section{RESEARCH IN THE FIELD OF PHYSICAL EDUCATION}

The findings obtained in a study which has dealt with the issues of obesity, physical activity and motor abilities in pupils have been presented in this chapter. 
It is of great importance to monitor a prevalence of obesity, given the data showing that the worldwide prevalence of overweight and obesity in children increased by $10 \%$ in the period 1990-2010 (De Onis et al., 2010). In our country, the prevalence of overweight and obesity in pupils was estimated on a representative sample of the pupils of Belgrade schools, as a part of a national project. The sample consisted of 11,644 pupils, aged 9-15 years. The results have shown that the overall prevalence determined in the entire sample was $24.2 \%$, out of which $19.2 \%$ were overweight and 5\% were obese pupils. A higher prevalence of overweight and obesity was found in the boys in all age groups (Radisavljević Janić, Milanović, Živković, Mirkov, 2013). Additionally, the prevalence of overweight and obesity in the territory of Serbia was examined on a representative sample which consisted of the primary school pupils of the third to the eighth grade. The study included 101 schools, i.e. a total of 12,476 pupils, i.e. 6,309 boys and 6,167 girls were examined. The results have indicated that the prevalence of obesity in the Serbian pupils at the age ranging from the third to the eighth grade was $24.8 \%$, including $19.8 \%$ of overweight pupils and $5.0 \%$ of obese ones. According to the pupils' gender, it was determined that the overall prevalence of obesity was significantly higher in the boys (27.0\%) compared to the female pupils (22.4\%). This trend was observed in all age groups. In addition, according to the pupils' age, i.e. grade, the highest percentage of the children belonging to the overweight group as well as the obese group were the pupils of lower primary school grades, as determined both in the male and female pupils (Milanović, Radisavljević Janić, 2015).

In a transverse study included in the Fourth COSI Implementation Round, the data on the prevalence of obesity were obtained in 5,102 Serbian primary and secondary school pupils, aged 6 to 9 years. The results obtained in the study have shown that the prevalence of obesity varied in relation to different age groups, with the lowest prevalence rate determined in the 7 -year-old boys (6.2\%), and the highest prevalence rate was found in the 6-year-old boys (9.7\%). Excess body weight is significantly associated with poor local community development and a low level of urbanization. By comparing the overall prevalence of obesity (23.1\% - overweight and obesity combined) and the prevalence of obesity (6.9\%) in the Serbian children of a lower primary school age with the data obtained in their peers from other countries that participated in the COSI program, it may be concluded that this prevalence rate was quite high, which indicates an obesity epidemic in the children of this age in Serbia (Đorđić, Radisavljević, Milanović, Božić, Grbić, Jorga \& Ostojić, 2016).

According to the research on the prevalence of obesity in children and youth, based on the national data collected in 21 European countries in 1990 (Lobstain and Frelut, 2003), Serbia (as a part of the former Yugoslavia) had a prevalence of obesity in children and young people of $17 \%$ and it belonged to a group of the countries with a low prevalence of obesity. According to the findings of the three aforementioned studies, Serbia belonged to the group of the European countries with a low prevalence of obesity in the 1990s, however, it has recently come closer to the southwestern European countries where the prevalence of obesity is considerably higher than in the rest of Europe (Janssen et al., 2005).

The pupils' physical activity in our country has not been monitored continuously at the national level, and, to the knowledge of the authors of this paper, there is no individual research on physical activity conducted on a representative sample of pupils. For this reason, the paper has presented the studies that can serve as a course of action in order to assess the physical activity of pupils in our educational system. A level of pupils' physical activity was examined, in relation to their age and gender, in 838 pupils (472 pupils of the seventh and the eighth grade of primary school and 366 pupils of the first and second year of secondary school), using a Physical Activity Questionnaire for Adolescents (PAQ-A). The results have shown that there were differences in the level of physical activity found between primary and secondary school pupils in favor of the primary school pupils (early adolescence). Also, the gender differences in the level of physical activity were determined in both age groups in favor of the male adolescents. According to some segments of the overall physical activity, the highest level of physical activity was found to be during physical education classes, as determined in the adolescents of both genders, in both primary and secondary school. The male pupils, in relation to the female ones, showed a higher level of activity in most segments of the overall physical activity at both ages. It is necessary to pay a special attention to the transition from primary to secondary school, adolescents' 
gender and their interests in specific sports and types of physical activity, when designing the programs aimed at improving the physical activity of adolescents in the context of physical education classes (Radisavljević-Janić, Milanović, Lazarević, 2012). The level of physical activity and energy consumption in the adolescents from the urban environments in Serbia in relation to the adolescents' physical status and gender was measured by a direct assessment using a SWA device (Sense Wear PRO3 Armband device). The obtained results have indicated that the girls were less active than the boys, at all physical activity levels. In addition, it was found that the girls spent less time in physical activity during weekends than during working days. Early adolescence is a period critical for giving up physical exercise in pupils, especially girls, and in this sense, the results have contributed to a better understanding of the differences that occur in boys and girls when it comes to their participation in physical exercise (Pašić, Milanović, Janić Radisavljević, Jurak, Sorić and Mirkov, 2014).

The motor abilities of the pupils in the Republic of Serbia were examined on a representative sample in April and May 2014. The research involved 12,476 primary school pupils of the third to the eighth grade. Regarding motor abilities, the obtained results are consistent with the findings of the similar studies conducted worldwide which have confirmed the trend that boys, regardless of their age, demonstrate better motor skills, except for flexibility where girls are rather dominant. Since there is a lack of results of the longitudinal studies on pupils' motor abilities conducted in the previous period, it is impossible to make a comparison of the findings obtained in this research (Milanović, Radisavljević Janić, 2015).

The results of the research conducted under the Active youth healthier life: Health, lifestyles and physical fitness of young people project that included 2,814 secondary school pupils in the territory of the city of Belgrade, aged 15 to 18 years, and which lasted for 6 months (August - December 2015), have indicated an inadequate level of physical fitness associated with health ( $60 \%$ of the male pupils and even $87 \%$ of the female ones were found to be below the recommended values), daily physical activity (56\% of the male pupils and even $75 \%$ of the female pupils did not meet the minimum volume recommended). Regarding the healthy lifestyle behaviors represented among the secondary school pupils, quite disturb- ing findings have been obtained, indicating that only $2 \%$ of the male pupils and less than $1 \%$ of the female ones demonstrated a preferred lifestyle which, according to this study, implied that a pupil meets the minimum standards in terms of physical fitness, daily physical activity, nutrition, fruit and vegetable intake and over-salting (Guide to the Physical Activity and Nutrition of Youth, 2016).

\section{CONCLUSION}

Although the importance of physical education has been recognized in the legal framework, by the recommendations contained in the adopted regulations and measures, they have not been implemented or practically applied to a greater extent. The competent institutions should be guided by the practice of most European Union countries that have adopted the National Physical Education Strategy (Eurydice, 2013). In this context, it is also necessary to consider the good practice examples of some countries, such as Hungary, which, in addition to three PE classes per week, introduced two additional weekly classes to primary school pupils, which is funded by the local self-government. Providing the uniform conditions for physical education teaching at the state level, i.e. throughout the country, should be set as a priority, since they are one of the most important factors for a quality physical education. Moving the emphasis away from the learning content towards the learning process and its outcomes, introducing the mandatory monitoring, evaluating and recording of pupils' physical abilities and allowing pupils to be exempted only from a practical part of the PE course with the obligation to attend all classes are significant novelties in the subject bearing a new name. In regard to the existing educational standards, it is necessary to examine the extent to which pupils have acquired knowledge and skills and develop their motor abilities upon completion of their compulsory education, which is questionable without providing the optimal conditions for physical education teaching. Mandatory professional development of physical education teachers aimed at acquiring the new competences and improving the existing ones is relevant for the improvement of educational work. It is necessary to introduce a continuous monitoring of the preva- 
lence of obesity, level of physical activity and motor abilities in pupils, at the national level (Slovenia is a good example). It is also necessary to involve parents in this process, as they are responsible for developing healthy eating habits in early childhood. At the school level, a course of action should be oriented towards promoting healthy eating lifestyles and en-

\section{REFERENCES}

1. Cardon, G., De Bourdeaudhuij, I. \& De Clercq, D. (2002). Knowledge and perceptions about back education among elementary school students, teachers, and parents in Belgium, Journal of School Health, 72(3), 100-106.

2. De Onis, M., Blössner, M., \& Borghi, E. (2010). Global prevalence and trends of overweight and obesity among preschool children-. The American journal of clinical nutrition, 92(5), 1257-1264.

3. Djordjic, V., Radisavljevic, S., Milanovic, I., Bozic, P., Grbic, M., Jorga, J., \& Ostojic, S. M. (2016). WHO European Childhood Obesity Surveillance Initiative in Serbia: a prevalence of overweight and obesity among 6-9-year-old school children. Journal of Pediatric Endocrinology and Metabolism.

4. European Commission/EACEA/Eurydice, 2013. Physical Education and Sport at School in Europe Eurydice Report. Luxembourg: Publications Office of the European Union.

5. Hardman, K. (2009). Odabrana pitanja. izazovi i odluke u fizičkom vaspitanju. [Selected questions. challenges and decisions in physical education]. Zbornik radova sa međunarodne naučne konferencije „Teorijski, metodološki i metodički aspekti fizičkog vaspitanja“ (стр.11-21)..Beograd: Fakultet sporta i fizičkog vaspitanja,

6. Извештај: Истраживане стаюа у образовноваспитним установама у Србији у вези са школским спортом (2008). [Report: Survey of the situation in educational institutions in Serbia regarding school sport. In Serbian]. Beograd: Завод за вредновање квалитета образовања и васпитања.

7. Janssen I., Katzmarzyk, P.T., Boyce, W.F., et al. (2005). Comparison of overweight and obesity prevalence in school-aged youth from 34 coun- couraging children to participate in physical activity from the lowest grades. A minimum of 30 minutes, i.e. an optimum of 60 minutes of being engaged in a physical activity on a daily basis, as recommended in order to ensure the proper child development, could be accomplished by an increased number of physical education classes on a weekly basis.

tries and their relationships with physical activity and dietary patterns. Obesity Reviews, 6, 123-132.

8. Lobstein, T. \& Frelut, M. L. (2003). Prevalence of overweight among children in Europe. Obesity Reviews, 4(4), 195-200.

9. McBride, N. \& Midford, R. (1999). Encouraging Schools to Promote Health: Impact of the Western Australian School Health Project (19921995). Journal of School Health, 69(6), 220-226.

10. Milanović, I., Radisavljević Janić, S. \& Višnjić, D. (2014). Cilj i zadaci fizičkog vaspitanja u kontekstu društvenih i istorijskih promena u Srbiji. [Goal and tasks of physical education in the context of social and historical changes in Serbia. In Serbian]. U S. Pantelić (ur.), Zbornik radova (str. 87-98. Niš. Fakultet sporta i fizičkog vaspitanja.

11. Mićić, B. (2013). Oslobađanje učenika od nastave fizičkog vaspitanja. [Release of pupils from teaching physical education. In Serbian]. Diplomski rad. Beograd: Fakultet sporta i fizičkog vaspitanja.

12. Predlog mera za unapređenje nastave fizičkog vaspitanja [Proposal for measures to improve the teaching of physical education. In Serbian] (2013). Nacionalni prosvetni savet. Dostuno na (https://www.cipcentar.org/.../Mere\%20za\%20 unapredjivanje\%20FV)

13. Nikolić, S. (2003-2004). Struktura objekata za fizičko vaspitanje u školama na teritoriji Beograda. [Structure of physical education facilities in schools in the territory of Belgrade]. Fizička kultura, 57-58(1-4), 90-94.

14. Pašić, M., Milanović, I., Janić, S. R., Jurak, G., Sorić, M. \& Mirkov, D. M. (2014). Physical activity levels and energy expenditure in urban Serbian adolescents-a preliminary study. Nutricion hospitalaria, 5(30), 1044-1053. 
15. Radisavljević Janić, S., Milanović, I., Živković, M. \& Mirkov, D. (2013). Prevalence of overweight and obesity among Belgrade youth: A study in a representative sample of 9-14-year children and adolescents, Anthropological Notebooks, .19(3), 71-80.

16. Radisavljević-Janić, S., Milanović, I. \& Lazarević, D. (2012). Fizička aktivnost adolescenata - uzrasne i polne razlike. [Physical activity of adolescents - age and gender differences]. Nastava $i$ vaspitanje, 61(1), 183-194.

17. Radisavljević Janić, S., Milanović, I.\& Mirkov, D., (2013). Fizička aktivnost i motoričke sposobnosti adolescenata sa normalnom i prekomernom telesnom težinom. [Physical activity and motor abilities of adolescents with normal and overweight. In Serbian] U M. Dopsaj, I. Juhas, G. Kasum (ur), Tematski zbornik radova Međunarodna naučna konferencija "Efekti primene fizičke aktivnosti na antropološki status dece, omladine i odraslih (str 630-638). Beograd: Univerzitet u Beogradu, Fakultet sprta i fizičkog vaspitanja.

18. Shephard, R.J. \& Trudeau, F. (2000). The legacy of physical education: Influences on adult lifestyle. Pediatric Exercise Science, 12(1), 34-50.

19. Šunkić, J. (2016). Mišljenje nastavnika o izostajanju i oslobađanju učenika od nastave fizičkog vaspitanja. [The teacher's opinion on the absence and release of students from the teaching of physical education. In Serbian]. Diplomski rad, Beograd: Fakultet sporta i fizičkog vaspitanja.

\section{Documents}

1. Vodič za fizičku aktivnost i ishranu mladih. [A Guide to Physical Activity and Nutrition of Young People. In Serbian]. Dostupno na: http://www. chess.edu.rs/wp-content/uploads/2016/03/vodic fizicka_aktivnost_ishrana_mladih-za-sajt.pdf

2. Zakon o osnovama sistema obrazovanja $i$ vaspitanja (2017) [Law on the basics of the education system. In Serbian]. Službeni glasnik RS - Prosvetni glasnik 88/2017.

3. Zakon o osnovnom obrazovanju $i$ vaspitanju (2017). [Law on Primary Education. In Serbian]. Službeni glasnik RS i Prosvetni glasnik 55/2013 и $101 / 2017$.
4. Zakon o osnovnom obrazovanju $i$ vaspitanju (2013). [Law on Primary Education. In Serbian]. Službeni glasnik RS - Prosvetni glasnik br. $55 / 2013$.

5. Zakon o srednjem obrazovanju $i$ vaspitanju (2013). [Law on Secondary Education. In serbian]. Službeni glasnik RS i Prosvetni glasnik br. $55 / 2013$.

6. Obrazovni standardi za kraj obaveznog obrazovanja za nastavni predmet fizičko vaspitanje (2009). [Educational standards for the end of compulsory education for teaching subject physical education. In Serbian]. Službeni glasnik RSProsvetni glasnik, br.. 72/2009.

7. Pravilnik o normativima školskog prostora, opreme i nastavnih sredstava za osnovnu školu (1990). [Rule book on the norms of school premises, equipment and teaching materials for elementary school. In Serbian]. Službeni glasnik RS - Prosvetni glasnik, br. 4/1990.

8. Program fizičkog i zdravstvenog vaspitanja za osnovnu školu (1986). [Physical and health education program for elementary school. In Serbian]. Fizička kultura. 2.

9. Program fizičkog $i$ zdravstvenog vaspitanja $z a$ osnovnu školu (1990). [Physical and health education program for elementary school. In serbian]. Službeni glasnik RS - Prosvetni glasnik, br. 4/1990)

10. Program fizičkog vaspitanja za osnovnu školu (2004). [Physical education program for elementary schoo. In Serbian]. Službeni glasnik RS Prosvetni glasnik, br. 10/2014.

11. Program fizičkog $i$ zdravstvenog vaspitanja za peti razred osnovne škole (2017). [Physical and health education program for fifth grade of elementary school. In Serbian]. Službeni glasnik RS - Prosvetni glasnik, br. 6/2017.

12. Pravilnik o standardima kompetencija za profesiju nastavnika i njihovog profesionalnog razvoja (2011). [Rule book on competence standards for the profession of teachers and their professional development. In Serbian]. Službeni glasnik RS Prosvetni glasnik, br. 5/2011.

13. Pravilnika o stalnom stručnom usavršavanju $i$ sticanju zvanja nastavnika, vaspitača $i$ stručnih saradnika (2013). [Rule book on continuous professional development and acquisition of the title 
of teachers, educators and professional associates. In Serbian]. Službeni glasnik RS - prosvetni glasnik, br. 85/13

14. Pravilnik o stalnom stručnom usavršavanju nastavnika, vaspitača i stručnih saradnika (2015). [Rulebook on continuous professional development of teachers, educators and professional associates. In Serbian]. Službeni glasnik RS- Prosvetni glasnik, br. 86/2015.

15. Pravilnik o izmenama i dopunama Pravilnika o nastavnom planu za drugi ciklus osnovnog obrazovanja $i$ vaspitanja i nastavnom programu za peti razred osnovnog obrazovanja $i$ vaspitanja (2017). [Rule book on amendments to the Curriculum Ordinance for the second cycle of elementary education for the fifth grade of elementary education. In Serbian]. Službeni glasnik RS - Prosvetni glasnik, br. 6/2017.
16. Stručno uputstvo o postupku za oslobađanje učenika osnovne i srednje škole od nastave fizičkog vaspitanja. (1993). [Expert instruction on the procedure for the release of primary and secondary school pupils from the teaching of physical education.In Serbian]. Republika Srbija, Ministarstvo prosvete, Beograd.

17. Уредба о Начионалном програму превенције, лечена и контроле кардиоваскуларних болести у Републици Србији до 2020 (2010) [Regulation on the National Program for the Prevention, Treatment and Control of Cardiovascular Diseases in the Republic of Serbia until 2020]. 


\title{
ФИЗИЧКО ВАСПИТАҢЕ У РЕПУБЛИЦИ СРБИЈИ
}

\author{
Снежана Радисављевић Јанић, Ивана Милановић \\ Факултет спорта и физичког васпитања, Универзитет у Београду, Србија
}

\begin{abstract}
Сажетак
Физичко васпитање, као интегрални део обавезног образовања, има значајну улогу у промовисању и унапређивању физичке активности деце и младих. У односу на промене у одређеним сегментима физичког васпитања, у периоду од пуне државне независности Републике Србије, анализом су обухваћени: законски оквир и усвојена документа, план и програм, услови за наставу физичког васпитања, образовни стандарди, наставнички кадар, ослобађање ученика од наставе физичког васпитања и истраживања у физичком васпитању. Значај физичког васпитања, који је препознат у законском оквиру, препорукама у донетим уредбама и мерама, није преточен у праксу. У том контексту, повећање броја часова и уједначавање услова за наставу физичког васпитања на нивоу читаве државе требало би поставити као приоритет. Померање тежишта са наставних садржаја на процес учења и његове резултате, увођење обавезног праћења, вредновања и евидентирања физичких способности ученика и ослобађање ученика само од практичног дела наставе, уз обавезу да присуствују часовима, су значајне новине у оквиру предмета са новим називом (Физичко и здравствено васпитање). Неопходна је провера достигнутости образовних стандарда, односно у којој мери су ученици стекли знања и вештине и развили моторичке способности на крају обавезног образовања. Обавезно стручно усавршавање наставника физичког васпитања у циљу стицања нових и усавршавања постојећих компетенција важно је за унапређење образовно-васпитног рада. Резултати истраживања указују на неопходност континуираног праћења преваленце гојазности, нивоа физичке активности и моторичких способности ученика на националном нивоу, као и промоцију здраве исхране и подстицање деце на физичку активност.
\end{abstract}

КљУчНе речИ: ФИЗИЧКО ВАСПИТАҢЕ / ПЛАН И ПРОГРАМ / ОБРАЗОВНИ СТАНДАРДИ / СРБИЈА

\section{УВОД}

У промовисању и унапређивању физичке активности деце и младих, школа је најважнија институција (McBrideand Midford 1999; Cardonand Bourdeaudhuij 2002), а физичко васпитање у овом процесу има кључну улогу (Shephard and Trudeau 2000). Физичко васпитање, као наставни предмет има проширену улогу и посебну одговорност која се огледа у томе што се садржајима овог предмета обрађују многа савремена питања у оквиру образовног процеса са карактеристикама које не нуди ни једно друго наставно и школско градиво (Хардман, 2009). Такође, он је „једини школски предмет, у оквиру којег се деца припремају за здрав живот и усмерен је на њихов целокупни физички и ментални развој. Кроз њега се преносе важне друштвене вредности као што су правичност, самодисциплина, солидарност, толеранција, тимски дух и фер плеј“ и да се заједно са спортом сматра „једним од најважнијих оруђа у социјалној интеграцији“ (Хардман, 2009). Физичко васпитање представља интегрални део обавезног образовања, како у земљама Европе, тако и у Србији. У односу на промене у одређеним сегментима физичког васпитања, у периоду од десет година, анализом су обухваћени: Законски оквир и усвојена документа, Наставни план и програм, Услови за наставу физичког васпитана, Образовни стандарди, Наставнички кадар, Ослобађане ученика од наставе физичког васпитања и Истраживања у физичком васпитању. 


\section{ФИЗИЧКО ВАСПИТАҢЕ: Законски оквир и усвојена документа}

Физичко васпитање (ФВ) се у ширем друштвеном контексту може сагледати и кроз значај који му се придаје у закону и усвојеним документима. Законом о основама система образовања и васпитања $(2009,2017)$, један од изиьева образовно-васпитног рада који се може остварити кроз наставу физичког васпитать je „развој и практиковање здравих животних стилова, свести о важности сопственог здравља и безбедности, потребе неговања и развоја физичких способности." Значај физичког васпитања, одређени проблеми са којим се овај предмет суочава, као и могући правци деловања, истакнути су у различитим документима који су на нивоу Републике Србије усвојени. У Стратегији развоја образовања у Србији до 2020. године (2012) уочено је да је „здравствено-спортска подршка развоју деце веома слаба. Спорт је доступан углавном талентованим ученицима, али и поред тога што јесте део редовних школских активности усмерених на развој деце и улагање у њихово здравље, спортске секције се плаћају по школама, велики број ученика се ослобађа наставе физичког васпитања, а објективне потребе су све веће." Да је проблем недовољне и неадекватне физичке активности достигао ниво националних размера у Србији, показује доношење уредбе о Националном програму превенције, лечења и контроле кардиоваскуларних болести у Републици Србији до 2020. године (2010), у којој је истакнуто да је $18.3 \%$ становништва гојазано, а 74.3\% није довољно физички активно. Као једну од мера, ова уредба истиче потребу „усаглашавања препорука здравствене струке у вези са повећањем фонда часова физичког васпитања у плановима и програмима редовне наставе за основно и средње образовање".

Национални просветни савет је на својој 78. седници, одржаној 29. маја 2012. године, полазећи од укупне забрињавајуће ситуације стања психофизичких способности деце и омладине, постуралних поремећаја и присуства све већег броја хроничних незаразних болести као последице услова живота и недовољне физичке активности, закључио да је потребно формирати ширу, међуресорну радну групу која би требало да предложи које мере треба предузети ради побољшања здравља и психофизичких способности деце и омладине. Мере за унапређивање наставе физичког васпитања донете су 2013. Године, са закључком да је потребно „унапређивати услове за реализацију наставе физичког васпитања као интегралног дела васпитно-образовног система."

\section{ПЛАН И ПРОГРАМ ФИЗИЧКОГ ВАСПИТАҢА}

Предмет физичко васпитање је обавезан предмет за ученике основне и средње школе. У првом циклусу основног образовања (1-4 разред) остварује се са недељним фондом од три часа, a у другом циклусу образовања (5-8 разред) недељни фонд је 2 часа. Статус трећег часа физичког васпитања, био је регулисан Стручним упутством (бр. 110-00-449-05/02 од 22. јуна 2005), министра просвете и спорта о организовању спортских активности у основној школи, након чега је у Наставни план основног образовања и васпитања уведен Обавезни програм - изабране спортске гране који се остваривао са по једним часом недељно. Уместо њега, 2007. године уводи се потпуно нови предмет Физичко васпитање - изабрани спорт, из групе обавезно изборних предмета (Службени гласник РС, 6/2007).

Од школске 2017/2018. године за ученике петог разреда, уместо предмета физичко васпитање, уведен је нови предмет, чији је назив у складу са захтевом министарства просвете, науке и технолошког промењен у Физичко и здравствено васпитање што је условило „уградњу“ садржаја из здравственог васпитања у програм (Правилник о изменама и допунама правилника о наставном плану за други циклус основног образовања и васпитања и наставном програму за пети разред основног образовања и васпитања, 2017). Овај предмет се остварује са недељним фондом од 2 часа физичког и здравственог васпитања и 1,5 часа обавезних физичких активности. Програмски садржаји некадашњег предмета физичко васпитање - изабрани спорт, сада се налазе у 
обавезним физичким активностима ученика (1,5 час недељно) и увезани су са програмом предмета, и допуњени новим садржајима.

У раду су програми ових предмета представљени у односу на следеће елементе: циљ, задаци, тематска подручја програма, садржаји програма, организациони облици рада и методичка упутства за реализацију програма. Циљ предмета физичко васпитање је да се разноврсним и систематским моторичким активностима, у повезаности са осталим васпитно - образовним подручјима, допринесе интегралном развоју личности ученика (когнитивном, афективном и моторичком), развоју моторичких способности, стицању, усавршавању и примени моторичких умења, навика и наопходних теоријских знања у свакодневним и специфичним условима живота и рада. Овај програм физичког васпитања конкретизује циљ физичког васпитања кроз дефинисање следећих задатака наставе физичког васпитања: подстицање раста, развоја и утицање на правилно држање тела; развој и усавршавање моторичких способности; стицање моторичких умења која су, као садржаји, утврђени програмом физичког васпитања и стицање теоријских знања неопходних за њихово усвајање; усвајање знања ради разумевања значаја и суштине физичког васпитања дефинисаног циљем овог васпитно - образовног подручја; формирање морално вољних квалитета личности; оспособљавање ученика да стечена умења, знања и навике користе у свакодневним условима живота и рада; стицање и развијање свести о потреби здравља, чувања здравља и заштити природе и човекове средине. Програм васпитно - образовног подручја усмерен је на: развијање физичких способности, усвајање моторичких знања, умења и навика и теоријско образовање. Садржаји програма су: атлетика, вежбе на справама и тлу, спортска игра (рукомет, кочарка, одбојка) и ритмичка гимнастика и народни плесови. Поред часа физичког васпитања, као основног организационог облика рада, предвиђени су и други организациони облици рада који треба да допринесу усвајању оних умења и навика који су од значаја за свакодневни живот и реализују се у ванчасовној и ваншколској организацији: корективно - педагошки рад, слободне активности - секције, активности у природи (излети, кросеви, логоровање, зимовање), школска и друга такмичења, спортске активности од значаја за друштвену средину и курсни облици рада. У програму су детаљно наведена дидактичко-методичка упутства за његову реализацију.

Циљеви наставе и учења свих наставних предмета за ученике петог разреда су нови и формулисани тако да је тежиште померено са садржаја учења на сврху учења. Сходно оваквој оријентацији, циљ наставе и учења физичког $u$ здравственог васпитағьа је да ученик унапређује физичке способности, моторичке вештине и знања из области физичке и здравствене културе, ради очувања здравља и примене правилног и редовног физичког вежбања у савременим условима живота и рада. Уместо тематских подручја дефинисане су наставне области: Физичке способности, Моторичке вештине, спорт и спортске дисциплине и Физичка и здравствена култура. Садржаји програма су: Атлетика, Спортска гимнастика, Основе тимских и спортских игара, Плес и ритмика и Пливање. Сви садржаји предмета су подељени на обавезне и препоручене узимајући у обзир узраст ученика и материјално-техничке услове у школама. Програм садржи следеће организационе облике рада: часови физичког и здравственог васпитања; обавезне физичке активности ученика; слободне активности - секције; недеља школског спорта; активности у природи (кросеви, зимовање, летовање - камповање); школска и ваншколска такмичења; корективно - педагошки рад. Дидактичко-методички елементи су сведени на основне информације.

Главна промена у савременој концепцији и пракси образовања и васпитања, па тако и у програму предмета физичко и здравствено васnuтағе, је померање тежишта са наставних садржаја на јасно дефинисане исходе, односно са наставних садржаја на процес учења и његове резултате. Исходи су формулисани тако да дају опис шта ће ученик бити у стању да уради кад заврши област/тему.

У оквиру предмета физичко и здравствено васпитане обавезно је праћење, вредновање и евидентирање физичких способности ученика које сеспроводи напочеткуи крајушколскегодине, на основу Приручника за праћење физичког развоја и развоја моторичких способности ученика у настави физичког васпитања, (Завод за вредновање квалитета образовања и васпитања, 
2016). У овом приручнику детаљно су објашњени: модел континуираног праћења физичког развоја и моторичких способности, батерија тестова, критеријумске референтне вредности и начин њиховог тумачења, организација и протокол тестирања као педагошке импликације.

\section{УСЛОВИ ЗА НАСТАВУ ФИЗИЧКОГ ВАСПИТАњА}

Објекти и опрема $\boldsymbol{c y}$, поред број часова, садражаја програма физичког васпитања, броja ученика и наставничких компетенција, један од фактора који утичу на квалитет физичког васпитања. Иако је Правилником о нормативима школског простора, опреме $u$ наставних средстава у основној школи (1990) регулисанодасвепотпунеосновнешколеимајусалу за физичко васпитање са пратећим просторијама, у нашем образовно-васпитном систему услови за наставу физичког васпитања нису уједначени на територији читаве државе, а никада није ни урађена њихова свеобухватна анализа. Анализа материјалних простора за реализацију наставе физичког васпитања, у 96 основних и средњих школа на територији града Београда је урађена пре скоро две деценије. Резултати су показали да затворена вежбалишта поседује 65.6\% школа, отворена игралишта $64.6 \%$, пратеће просторе $32.3 \%$, справарнице $53.1 \%$, кабинет за наставнике $78.1 \%$ обухваћених школа. Приближно $10.4 \%$ школа поседује услове за извођење наставе у редукованом облику (Николић, 2003-2004). Из наведених података се може уочити да у то време на територији града Београда око $20 \%$ школа није имало затворена вежбалишта. Остаје нејасно како је у тим школама настава физичког васпитања уопште реализована. У оквиру Истраживање стања у образовно-васпитним установама у Србији у вези са школским спортом (Завод за вредновање квалитета образовања и васпитања, 2008) анализирани су услови за наставу физичког васпитања у 1533 школе (1135 основне и 398 средње школе) Републике Србије. Резултати су показали да $63.5 \%$ школа има велику салу а $22.4 \%$ школа има малу салу. Из обиља података у овом истраживању не може се закључити колико школа нема салу за наставу физичког васпитања. Неопходна је израда правилника о нормативима школског простора, опреме и наставних средстава за наставу физичког васпитања у образовно-васпитном систему. ТакоЂе, потребно је урадити анализу постојећег стана услова и опреме за наставу физичког васпитања, ито би био почетак дефинисаюа плана за његово решавање.

\section{НАСТАВНИЧКИ КАДАР}

У оквиру овог поглавља разматра се: школовање кадра, мастер диплома као неопходан услов за рад у образовању, стручно усавршавање наставникаистандардикомпетенцијазапрофесију наставника и њиховог професионалног развоја. Школовање кадра за рад у ФВ се врши на четири државна Факултета спорта и физичког васпитања у Београду, Новом Саду, Нишу и Лепосавићу, као и и на Државном факултету у Новом Пазару у оквиру Департмана за биомедицинске науке. Поред државних факултета, наставнички кадар за рад у образовању се такође школује и на већем броју приватних факултета. Од школске 2005/06. за рад у образовању неопходан услов је и мастер диплома. Саставни и обавезни део професионалног развоја наставника је стручно усавршавање које подразумева стицање нових и усавршавање постојећих компетенција важних за унапређивање образовно-васпитног рада (Правилник о сталном стручном усавршавању и стицању звања наставника, васпитача и стручних сарадника, 2013). Лични план професионалног развоја наставника сачињава се на основу самопроцене нивоа развијености свих компетенција за професију наставника, васпитача и стручног сарадника. Наставник $Ф B$, као и сви други наставници, дужан је да у току пет година оствари најмање 100 бодова из различитих облика стручног усавршавања, од чега најмање 80 бодова из одобрених програма стручног усавршавања (Правилник о сталном стручном усавршавању наставника, васпитача и стручних сарадника, 2015). У каталогу програма стручног усавршавања, који одобрава Завод за унапређивање образовања и васпитања, одређени програми стручног усавршавања намењени су наставницима физичког васпитања. 
Број ових програма се кретао од 6 за школску 2006/2007, до 29 за 2018/20 (2006/2007 - 6;2007/2008 - 10;2008/2009 - 13;2009/20010 - 22;2010/2011 - 9; 2011/2012 - 8; 2012/2014 - 12;2014/2016 - 14; 2016/2018 - 23 и 2018/20 - 29).

Од 2011. године утврђени су стандарди компетенција за професију наставника и њиховог професионалног развоја (Pravilnik o standardima kompetencija za profesiju nastavnika i njihovog profesionalnog razvoja, 2011). За све наставнике, па и за наставнике физичког васпитања, наставничке компетенције су капацитет појединца који се исказује у вршењу сложених активности у образовно-васпитном раду. Компентеције представљају скуп потребних знања, вештина и вредносних ставова наставника. Наставничке компетенције одређују се у односу на циљеве и исходе учења и треба да обезбеде професионалне стандарде о томе какво се поучавање сматра успешним. Односе се на компентенције за: наставну област, предмет и методику наставе; поучавање и учење; подршку развоју личности ученика и комуникацију и сарадњу.

\section{ОБРАЗОВНИ СТАНДАРДИ}

У оквиру пројекта Подрика осигурану квалитетасистемазавринихиспитананационалном нивоу у основном и среднем образовану (ИПА 2008), развијани су и донети образовни стандарди за крај обавезног образовања за све предмете, па и за физичко васпитање. Образовни стандарди за крај обавезног образовања за наставни предмет ФВ усвојени су 2009. године (Просветни гласник, 2009). Образовни стандарди су искази о темељним знањима, вештинама и умењима које ученици треба да стекну до одређеног нивоа у образовању. За предмет ФВ образовни стандарди дефинисани су за четири области: оспособљеност у вештинама, знања о физичком вежбању и физичком васпитању $u$ вредновање физичког вежбања и физичког васпитања од стране ученика. Област оспособљеност у вештинама чине савладани садржаји програма_ФВ у спортским играма (кошарка, одбојка, рукомет или фудбал), атлетици (трчање, скокови, бацање), вежбама на справама и тлу (тло, прескок, греда, двовисински разбој, кругови, коњ са хватаљкама, вратило, разбој), плесу, ритмичкој гимнастици, пливању, вежбама обликовања и стоном тенису. Област знања о физичком вежбању и физичком васпитању чине појмови који се користе у физичком вежбању, знања о основним принципима вежбања и правила спортских игара и индивидуалних спортова. Област вредновање физичког вежбања и физичког васпитања од стране ученика чине уверења, ставови и вредности које ученик поседује на крају основног образовања о физичком вежбању и физичком васпитању. Стандарди се периодично ревидирају и унапређују и ревизија образовних стандарда је учињена 2013. године кроз пројекат Подршка развоју тудског капитала и истраживану Oпште образоване и развој тудског капитала “Развионица"(ИПА, 2011). Поред претходно 3 дефинисане области у ФВ, предложена је и област моторичке способности, тако да су образовни стандарди за предмет ФВ дефинисани за следеће области: област оспособљеност у вештинама односи се на усвојеност елемената: једне спортске игре, атлетике, вежби на справама и тлу, плеса, ритмичке гимнастике, пливања и вежби обликовања; област моторичке способности односи се на развијеност моторичких способности ученика у односу на пол и узраст; знања о физичком вежбању и физичком васпитању садрже појмове о физичком вежбању и основна правила вежбања, правила спортских игара и индивидуалних спортова, смисао и утицај физичког вежбања и вредновање физичког вежбања и физичког васпитања односи се на уверења, ставове, интересовања, тимски рад, самоактуализацију ученика кроз физичко вежбање, физичке активности и процес физичког васпитања. Неопходно је напоменути да су образовни стандарди за предмет ФВ у оквиру пројекта Развионица (ИПА, 2011) били једна од основа за дефинисање исхода у ФВ, а такође су коришћени за дефинисање исхода за Наставни програм 5. разреда. 


\section{ОСЛОБАЂАЊЕ УЧЕНИКА ОД НАСТАВЕ ФИЗИЧКОГ ВАСПИТАҢА}

Ослобађање ученика од наставе физичког васпитања регулисано је законским оквиром, на основу Закона о основном образовању и васпитању (2013, члан 65), као и Закона о средњем образовању и васпитању (2013, члан 50), који предвиђају могућност ослобађања ученика од наставе физичког васпитања. Подзаконски акт за примену наведених чланова Закона прописало је Министарство просвете, 1993. године, у форми Стручног упутства. Овим стручним упутством је предвиђено да предлог за ослобађање ученика основне и средње школе од наставе физичког васпитања може дати лекар специјалиста или школски лекар, у зависности од здравственог стања ученика и насталог разлога за ово ослобађање. Ученик може бити привремено или за одређену школску годину ослобођен од наставе физичког васпитања делимично или у целини, ако због здравственог стања није у могућности да савлађује прописан програм физичког васпитања. Код привременог или делимичног ослобађања од наставе физичког васпитања ученик се оцењује из оног дела програма у коме је учествовао и обавезан је да присуствује свим часовима физичког васпитања. Када је у питању ослобађање од наставе физичког васпитања у целини за одређену школску годину, ученик се не оцењује из овог предмета и не присуствује часовима физичког васпитања када су они недељним распоредом часова предвиђени као први или последњи. Захтев за ослобађање ученика од наставе физичког васпитања могу да поднесу ученик или његов родитељ (старатељ). Потпун захтев ученика разматра се на наставничком већу, које доноси одлуку да је ученик ослобођен наставе физичког васпитања.

Физичко васпитање као обавезан предмет у основној и средњој школи има значајан допринос у унапређивању физичког вежбања ученика како у школи, тако и ван ње, али се без обзира на ову чињеницу суочава са проблемом великог броја ученика који су од наставе овог предмета ослобођени. Овај проблем је актуелан још од времена када је физичко васпитање постало део образовног процеса, а данас, уколико се не учини корак ка његовом решавању, може имати негативне последице за ученике. Иако је на основу малог броја истраживања указивано на постојање великог броја ученика ослобођених од наставе физичког васпитања, у нашој земљи на националном нивоу нема података о броју ослобођених ученика. Према истраживању о актуелном стању ослобођених ученика од наставе физичког васпитања у десет основних и седам средњих школа града Београда, у школској 2012/13. години, проценат ослобођених ученика од наставе физичког васпитања у основним школама се креће од $0 \%$ до $1.6 \%$, а у средњим од $1.1 \%$ до 8.3\% (Мићић, 2013). Када се особађање ученика од наставе физичког васпитања посматра преко укупног броја ослобођених ученика у овом истраживању, добија се забрињавајућа слика. У седам средњих школа је ослобођено 249 ученика, што практично значи да 8 одељења није обухваћено наставом физичког васпитања. У просеку по школи је 3.7\% ученика ослобођено од наставе физичког васпитања, што на први поглед није забрињавајуће, али посматрано на укупном броју уписаних ученика, од око 78000 у гимназијама и средњим стручним школама, у школској 2012/2013. години у Србији, онда би на нивоу читаве земље могло бити око 2880 ученика ослобођено од наставе физичког васпитања, односно 96 одељења. Ове претпостављене бројке указују на озбиљан проблем са образовног и здравственог аспекта. Резултати истраживања из 2016. године (Шункић, 2016) показују сличан тренд ослобађања ученика од наставе физичког васпитања у свим основним и средњим школама града Панчева. Ослобађање од наставе физичког васпитања у основним школама је на нивоу од 0-3\% ученика, док је у средњим школама израженије и креће се од 1-10\% ученика. У односу на резултате ова два истраживања и мишљење наставника из школа које су биле обухваћене, могу се извести одређени закључци. У основним школама ослобађање ученика је најчешће услед здравствених разлога, а у средњој школи већи број ученика се ослобађа од наставе физичког васпитања не искључиво из здравствених разлога, већ уз подршку родитеља и надлежног лекара, без постојања стварног здравственог разлога. Наставници физичког васпитања сматрају да има простора да се унапреди постојећа процедура по којој се ученици ослобађају од 
наставе физичког васпитања. Према мишљењу наставника физичког васпитања (Шункић, 2016), потребно је увођење предметне наставе у млађе разреде, едукација о значају физичког васпитања и увођење нових програма у складу са интересовањима и способностима ученика. У циљу смањења броја ученика који се ослобађа од наставе физичког васпитања, требало би правац деловања усмерити на ниво школе, кроз едукацију ученика о значају физичког васпитања, прилагођавање наставе ученицима са лакшим здравственим проблемима и чешће организовање активности у циљу промовисања вежбања, а на нивоу шире друштвене заједнице, кроз бољу информисаност о вредностима физичког васпитања и свеобухватнијем промовисању вежбања.

Нова формулација ослобађања ученика од наставе физичког васпитања у Закону о основама образовања и васпитања (2017) је потврда да је овај проблем уочен на нивоу Републике Србије. Према овом закону „ученик може бити привремено или за одређену школску годину ослобођен од практичног дела наставе физичког и здравственог васпитања у целини или делимично. Директор доноси одлуку о ослобађању ученика од практичног дела наставе физичког и здравственог васпитања на основу предлога изабраног лекара. Ученик који је ослобођен практичног дела наставе физичког и здравственог васпитања оцењује се на основу теоријских знања, у складу са програмом предмета." У програму физичког и здравственог васпитања за пети разред (2017) прецизније се дефинише да ученик може бити ослобођен само од практичног дела програма наставе за одређени период, полугодиште или целу школску годину на основу препоруке изабраног лекара. Ученик ослобођен практичног дела у обавези је да присуствује часовима. За рад са ослобођеним ученицима наставник сачињава посебан програм рада базиран на усвајању теоријских и васпитних садржаја у складу са програмом и корелацији са садржајимадругихпредмета.Такође, ослобођеним ученицима треба пружити могућност да: суде, воде статистику, региструју резултат или прате ниво активности ученика на часу или школском такмичењу, направе едукативни постер или електронску презентацију, припреме репортажу са спортског догађаја, снимају час и на други начин помажу наставнику у организацији, часовних, ванчасовних и ваншколских активности.

\section{ИСТРАЖИВАЫА У ФИЗИЧКОМ ВАСПИТАЬУ}

У овом поглављу представљени су резултати истраживања која су се бавила проблематиком гојазности, физичке активности и моторичких способности ученика. Праћење преваленце гојазности је веома важно с обзиром на податке који показују да се у свету дечија преваленца прекомерне масе тела и гојазности повећала за 10\% у периоду од 1990-2010. године (DeOnis et al., 2010). У нашој земљи процена преваленце прекомерне масе тела и гојазности ученика реализована је на репрезентативном узорку ученика из школа из Београда, као део националног пројекта. Узорак је чинило 11.644 ученика, узраста 9-15 година. Резултати показују да је укупна преваленца на целом узорку $24.2 \%$, од чега је $19.2 \%$ ученика са прекомерном телесном масом и 5\% гојазно. Утврђена је већа преваленца прекомерне телесне масе и гојазности код дечака у свим узрасним групама (Radisavljević Janić, Milanović, Živković, Mirkov, 2013). Такође, испитивана је преваленца прекомерне масе тела и гојазности на територији читаве Србије на репрезентативном узорку ученика основне школе од трећег до осмог разреда. Истраживањем је обухваћена 101 школа, односно мерено је укупно 12.476 ученика, 6.309 дечака и 6.167 девојчица. Резултати су показали да је преваленца гојазности ученика Србије на узрасту од трећег до осмог разреда $24,8 \%$, од тога је $19,8 \%$ ученика са прекомерном масом тела, а 5,0\% је гојазно. Када се посматрају дечаци и девојчице уочава се да је укупна преваленца гојазности код ученика знатно већа $(27,0 \%)$ у односу на ученице $(22,4 \%)$. Овај тренд се уочава на свим узрастима. Осим тога, посматрајући ученике према узрасту, односно по разредима, највећи проценат деце, која спадају у групу са прекомерном масом тела и у групу гојазних, је у млађим разредима основне школе, како код ученика, тако и код ученица (Милановић, Радисављевић Јанић, 2015).

У оквиру трансверзалног истраживања током четврте COSI Implementacione Runde (eng. Fourth 
COSI Implementation Round), прикупљени су подаци о преваленци гојазности 5102 ученика првог и другог разреда основне школе у Србији, узраста од 6 до 9 година. Резултати истраживања су показали да преваленца гојазности варира у односу на различите узрасне групе, са најмањом стопом преваленце код 7-годишњих дечака (6.2\%), и највећом стопом преваленце код 6-годишњих дечака (9.7\%). Прекомерна маса тела је значајно повезана са лошим развојем локалне заједнице и ниским нивоом урбанизације. Када се укупна преваленца гојазности (23.1\% - прекомерна маса тела и гојазност заједно) и преваленца гојазности (6.9\%) код српске деце млађег основношколског узраста упореди са подацима њихових вршњака из других земаља који су учествовали у програму COSI, може се закључити да је то прилично висока стопа преваленце која указује на епидемију гојазности код деце овог узраста у Србији (Djordjic, Radisavljevic, Milanovic, Bozic, Grbic, Jorga \& Ostojic, 2016).

Према истраживањима преваленце гојазности деце и младих, на основу националних података из 21 европске земље у периоду 1990. године (Lobstain and Frelut, 2003), Србија (део тадашње Југославије) је имала преваленцу гојазности деце и младих од $17 \%$ и спадала је у групу земаља са ниском преваленцом гојазности. Према резултатима три претходно наведена истраживања, Србија се из деведесетих година прошлог век,а када је била у групи земаља са нижом преваленцом гојазности у Европи, последњих година приближила земљама југозападне Европе у којима је преваленца гојазности знатно виша од осталих делова Европе (Janssen et al., 2005).

У нашој земљи не постоји континуирано праћењефизичкеактивностиученикананационалном нивоу, а према сазнањима аутора овог рада, такође нема ни појединачних истраживања о физичкој активности на репрезентативном узорку ученика. Из тог разлога у раду су приказана истраживања која могу послужити као правац деловања у циљу процене физичке активности ученика у нашем образовно-васпитном систему. Ниво физичке активности ученика 838 ученика (472 ученика седмог и осмог разреда основне школе и 366 ученика првог и другог разреда средње школе) испитиван је у односу на узраст и пол, применом Упитника физичке активности за адолесценте (PAQ-A). Резултати су показали да постоје разлике у нивоу физичке активности између ученика основне и средње школе у корист ученика основне школе (рани адолесцентски узраст). Такође, утврђено је постојање полних разлика у нивоу физичке активности у обе узрасне групе у корист адолесцената мушког пола. Посматрано према појединим сегментима укупне физичке активности, највиши је ниво физичке активности током часова физичког васпитања код адолесцената оба пола, у основној и у средњој школи. Ученици, у односу на ученице, показују виши ниво активности у већини сегмената укупне физичке активности на оба узраста. У програмима за унапређење физичке активности адолесцената у контексту наставе физичког васпитања, потребно је посебно имати у виду прелазни период од основне ка средњој школи, пол адолесцената и њихова интересовања за одређене спортове и облике физичке активности (RadisavljevićJanić, Milanović, Lazarević, 2012). Процена нивоа физичке активности и енергетске потрошње код адолесцената градске средине из Србије у односу на телесни статус и пол адолесцената реализована је директном проценом уз помоћ SWA апарата (Sense Wear PRO3 Armband device). Добијени резултати указују да су девојчице у односу на дечаке мање активне у свим нивоима физичке активности. Поред тога, код девојчица је време проведено у физичкој активности много мање током викенда, него током радних дана. Рана адолесценција је критични период за престанак бављења физичким вежбањем код ученика, посебно девојчица, и у том контексту резултати доприносе још бољем сагледавању разлика које се јављају код дечака и девојчица када је у питању бављење физичким вежбањем (Pašić, Milanović, Janić Radisavljević, Jurak, Sorić and Mirkov, 2014).

Мерење моторичких способности ученика Републике Србије реализовано је током априла и маја 2014. године на репрезентативном узорку. Истраживањем је обухваћено 12.476 ученика основнешколе,одтрећегдоосмогразреда.У оквиру моторичких способности добијени резултати су сагласни са резултатима сличних истраживања у свету који потврђују тренд да су дечаци, без обзира на узраст, бољи у свим моторичким способностима, осим када је у питању гипкост у којој су девојчице доминантније. Недостатак података лонгитудиналних истраживања о моторичким способностима ученика из ранијих 
периода онемогућава поређење добијених резултата у овом истраживању (Милановић, Радисављевић Јанић, 2015).

Резултати истраживања пројекта Активни млади здравији живот: Здравље, животни стилови и физичка форма младих којим је обухваћено 2814 ученика средњих школа на територији града Београда старости од 15 до 18 година, током 6 месеци (август - децембар 2015. године), указују на неадекватан ниво физичке форме повезане са здрављем (60\% ученика и чак $87 \%$ ученица се налазе испод препоручених вредности), дневне физичке активности (56\% ученика и чак $75 \%$ ученица не испуњавају минимални препоручени обим). У погледу заступљености здравих животних образаца понашања код ученика средњих школа добијени су прилично забрињавајући подаци који показују да само $2 \%$ ученика и мање од $1 \%$ ученица поседује пожељан животни профил који је у овом истраживању подразумевао да ученик задовољава минималне стандарде у погледу физичке форме, дневне физичке активности, ухрањености, уноса воћа и поврћа и досољавања хране (Водич за физичку активност и исхрану младих, 2016).

\section{ЗАКЉУЧАК}

И поред значаја физичког васпитања који је препознат у законском оквиру, препорукама у донетим уредбама и мерама, није се далеко одмакло са њиховом применом. Путоказ за надлежне институције требало би да буде пракса већине држава Европске уније које имају усвојене Националне стратегије физичког васпитања (Eurydice, 2013). У том контексту неопходно је сагледати и добре примере неких држава, као што је Мађарска, која је поред три часа физичког васпитања недељно за ученике основне школа увела још два часа недељно, а који се финансирају из средстава локалне самоуправе. Уједначавање услова за наставу физичког васпитања на нивоу читаве државе требало би поставити као приоритет, јер они представљају један од најважнијих фактора за квалитетно физичко васпитање. Померање тежишта са наставних садржаја на процес учења и његове резултате, увођење обавезног праћења, вредновања и евидентирања физичких способности ученика и ослобођање ученика само од практичног дела наставе уз обавезу да присуствују часовима, су значајне новине у оквиру предмета са новим називом. у погледу постојећих образовних стандарда неопходна је провера у којој мери су ученици стекли знања и вештине и развили моторичке способности на крају обавезног образовања, што се без оптималних услова за наставу физичког васпитања доводи у питање. Обавезно стручно усавршавање наставника физичког васпитања у циљу стицања нових и усавршавања постојећих компетенција, важно је за унапређивање образовно-васпитног рада. Неопходно је на националном нивоу континуирано праћење преваленце гојазности, нивоа физичке активности и моторичких способности ученика (добар пример је Словенија). У овај процес је неопходно укључити и родитеље, као носиоце навика везаних за здраву исхрану у раном дечијем узрасту. У оквиру школе правац деловања усмерити на промоцију здраве исхране и подстицање деце на физичку активност од најмлађих разреда. Препоруке о минималних 30 до оптималних 60 минута бављења неком физичком активношћу у току једног дана, како би се обезбедио правилан развој детета, било би могуће испунити кроз већи број часова физичког васпитања на недељном нивоу.

\section{ЛИТЕРАТУРА}

1. Cardon, G., De Bourdeaudhuij, I., De Clercq, D. (2002). Knowledge and perceptions about back education among elementary school students, teachers, and parents in Belgium, Journal of School Health, 72(3), 100-106.
2. De Onis, M., Blössner, M., \& Borghi, E. (2010). Global prevalence and trends of overweight and obesity among preschool children-. The American journal of clinical nutrition, 92(5), 1257-1264. 
3. Djordjic, V., Radisavljevic, S., Milanovic, I., Bozic, P., Grbic, M., Jorga, J., \& Ostojic, S. M. (2016). WHO European Childhood Obesity Surveillance Initiative in Serbia: a prevalence of overweight and obesity among 6-9-year-old school children. Journal of Pediatric Endocrinology and Metabolism.

4. European Commission/EACEA/Eurydice, 2013. Physical Education and Sport at School in Europe Eurydice Report. Luxembourg: Publications Office of the European Union.

5. Hardman, K. (2009). Odabrana pitanja. izazovi i odluke u fizičkom vaspitanju. Zbornik radova sa međunarodne naučne konferencije „Teorijski, metodološki i metodički aspekti fizičkog vaspitan$j a$ “. Fakultet sporta i fizičkog vaspitanja, Beograd, стр.11-21.

6. Извештај: Истраживање стања у образовноваспитним установама у Србији у вези са школскимспортом (2008).Заводза вредновање квалитета образовања и васпитања, Београд.

7. Janssen I., Katzmarzyk, P.T., Boyce, W.F., et al. (2005). Comparison of overweight and obesity prevalence in school-aged youth from 34 countries and their relationships with physical activity and dietary patterns. Obesity Reviews, 6, 123-132.

8. Lobstein, T., Frelut, M. L. (2003). Prevalence of overweight among children in Europe. Obesity Reviews, 4(4), 195-200.

9. McBride, N., Midford, R. (1999). Encouraging Schools to Promote Health: Impact of the Western Australian School Health Project (19921995). Journal of School Health, 69(6), 220-226.

10. Milanović, I., Radisavljević Janić, S., Višnjić, D. (2014). Cilj i zadaci fizičkog vaspitanja u kontekstu društvenih i istorijskih promena u Srbiji. U S. Pantelić (ur.), Zbornik radova (str. 87-98. Niš. Fakultet sporta i fizičkog vaspitanja.

11. Мићић, В. (2013). Ослобађање ученика од наставе физичког васпитања, Дипломски рад, Факултет спорта и физичког васпитања, Београд.

12. Предлог мера за унапређивање наставе физичког васпитања.(2013). Национални просветни савет.( https://www.cipcentar.org/.../ Mere\%20za\%20unapredjivanje\%20FV)
13. Nikolić, S. (2003-2004). Struktura objekata za fizičko vaspitanje u školama na teritoriji Beograda, Fizička kultura, 57-58(1-4), 90-94.

14. Pašić, M., Milanović, I., Janić, S. R., Jurak, G., Sorić, M., Mirkov, D. M. (2014). Physical activity levels and energy expenditure in urban Serbian adolescents-a preliminary study. Nutricion hospitalaria, 5(30), 1044-1053.

15. Radisavljević Janić, S., Milanović, I., Živković, M., Mirkov, D. (2013). Prevalence of overweight and obesity among Belgrade youth: A study in a representative sample of 9-14-year children and adolescents, Anthropological Notebooks, .19(3), 71-80.

16. Radisavljević-Janić, S., Milanović, I., Lazarević, D. (2012). Fizička aktivnost adolescenata - uzrasne i polne razlike, Nastava $i$ vaspitanje, 61(1), 183-194.

17. Радисављевић Јанић С., Милановић, И., Мирков, Д. (2013). Физичка активност и моторичке способности адолесцената са нормалном и прекомерном телесном тежином, У М. Допсај, И. Јухас, Г. Касум (ур.), Тематски зборник радова Међународне научне конференције „Ефекти примене физичке активности на антрополошки статус деце, омладине и одраслих" (стр.630-638), Београд: Универзитет у Београду - Факултет спорта и физичког васпитања.

18. Shephard, R.J., Trudeau, F. (2000). The legacy of physical education: Influences on adult lifestyle. Pediatric Exercise Science, 12(1), 34-50.

19. Шункић, J. (2016). Мишљење наставника о изостајању и ослобађању ученика од наставе физичког васпитања, Дипломски рад, Факултет спорта и физичког васпитања, Београд.

\section{Документа:}

1. Водич за физичку активност и исхрану младих http://www.chess.edu.rs/wp-content/uploads/2016/03/vodic_fizicka_aktivnost_ishrana_ mladih-za-sajt.pdf

2. Закон о основама система образовања и васпитања, (2017). Службени гласник РСПросветни гласник, бр. 88/2017. 
3. Закон о основном образовању и васпитању (2017). Службеном гласнику РС- Просветни гласник, бр. 55/2013 и 101/2017.

4. Закон о основном образовању и васпитању (2013). Службени гласник РС- Просветни гласник, бр. 55/2013.

5. Закон о средњем образовању и васпитању (2013). Службени гласник РС- Просветни гласник, бр.55/2013.

6. Образовни стандарди за крај обавезног образовања за наставни предмет физичко васпитање (2009). Службени гласник РС Просветни гласник, бр. 72/2009.

7. Pravilnik o normativima školskog prostora, opreme $i$ nastavnih sredstava za osnovnu školu (1990). Službeni glasnik RS - Prosvetni glasnik, br. 4/1990.

8. Program fizičkog i zdravstvenog vaspitanja za osnovnu školu (1986). Fizička kultura. 2.

9. Program fizičkog $i$ zdravstvenog vaspitanja za osnovnu školu (1990). Službeni glasnik RS - Prosvetni glasnik, br. 4/1990)

10. Program fizičkog vaspitanja za osnovnu školu (2004). Službeni glasnik RS - Prosvetni glasnik, br. 10/2014.

11. Program fizičkog $i$ zdravstvenog vaspitanja za peti razred osnovne škole (2017). Službeni glasnik RS Prosvetni glasnik, br. 6/2017.
12. Pravilnik o standardima kompetencija za profesiju nastavnika $i$ njihovog profesionalnog razvoja (2011). Službeni glasnik RS - Prosvetni glasnik, br. $5 / 2011$.

13. Правилника о сталном стручном усавршавању и стицању звања наставника, васпитача и стручних сарадника (2013). Службени гласник РС - просветни гласник, бр. 85/13

14. Правилник о сталном стручном усавршавању наставника, васпитача и стручних сарадника (2015). Службени гласник РС- Просветни гласник, бр. 86/2015.

15. Правилник о изменама и допунама Правилника о наставном плану за други циклус основног образовања и васпитања и наставном програму за пети разред основног образовања и васпитања (2017). Службени гласник РС - Просветни гласник, бр. 6/2017.

16. Стручно упутство о поступку за ослобађање ученика основне и средње школе од наставе физичког васпитања. (1993). Република Србија, Министарство просвете, Београд.

17. Уредба о Националном програму превенције, лечења и контроле кардиоваскуларних болести у Републици Србији до 2020, (2010). 